\title{
Androgenic alopecia in post-menopausal female: a clinical presentation
}

\author{
Kirty Nahar ${ }^{1 *}$, Usha Bohra1, Vivek Arya ${ }^{2}$
}

\begin{abstract}
${ }^{1}$ Department of Obstetrics and Gynecology, Apollo Hospital International Ltd., Ahmedabad, Gujarat, India
${ }^{2}$ Department of Endocrinology, Apollo Hospital International Ltd., Ahmedabad, Gujarat, India
\end{abstract}

Received: 29 December 2019

Revised: 23 January 2020

Accepted: 29 January 2020

\author{
*Correspondence: \\ Dr. Kirty Nahar, \\ E-mail: naharkirty@yahoo.co.in
}

Copyright: (c) the author(s), publisher and licensee Medip Academy. This is an open-access article distributed under the terms of the Creative Commons Attribution Non-Commercial License, which permits unrestricted non-commercial use, distribution, and reproduction in any medium, provided the original work is properly cited.

\begin{abstract}
Androgenic alopecia is a patterned hair loss occurring due to systemic androgens and genetic factors. It is the most common cause of hair loss in both genders. The appearance of this condition is the cause of significant stress and psychological problems, making appropriate management important. A 68-year-old postmenopausal female presented with complaints of increased hair loss from scalp, excessive hair growth at undesired sites and hirsutism not corrected with medications. On thorough investigations, CT scan whole abdomen and endocrinological workup, a clinical diagnosis of alopecia and hirsutism due to hyperandrogenemia secondary to ovarian tumor made. Abdominal hysterectomy with B/L salpingo-oophorectomy was done. Histopathological examination revealed an encapsulated tumor in right ovary-sex cord stromal tumor consistent with Leydig cell tumor in right ovary, no evidence of malignancy. Left ovary was normal. Patient showed significant regression of clinical signs and symptoms on follow up after 1 month. All women with severe hirsutism or androgenic alopecia needs further work up to locate the source of androgen over production.
\end{abstract}

Keywords: Androgenic alopecia, Hirsutism, Hyperandrogenism, Male pattern baldness, Sertoli-leydig cell tumor

\section{INTRODUCTION}

Hair plays an important role in social and sexual communication. People who have alopecia suffer from marked psychological distress. Androgenic alopecia is commonly seen in men with family history. Female androgenic alopecia is one of the most important causes of hair loss, affecting $50 \%$ of women over their life time. ${ }^{1}$ It is not surprising that hair loss in women can be a serious cause of psychological stress and morbidity. ${ }^{2,3}$ In one study, $55 \%$ of affected women displayed symptoms of depression. ${ }^{4}$ In that same group, $89 \%$ of women experienced an improvement of those symptoms after treatment for hair loss. ${ }^{4}$ Norwood-Hamilton grading is widely accepted for defining the degree of alopecia (male pattern baldness). According to Hamilton's study, the mean prevalence of androgenic alopecia is $30 \%$ by the age of 30 years, and this rate rises to $50 \%$ by the age of 50 years. ${ }^{5,6}$ Phenotype of Androgenic alopecia is different in men and women. In the male pattern, the hairline regresses at bitemporal regions and balding of the vertex occurs. In the female pattern there is diffuse thinning while the frontal hairline is preserved. ${ }^{7,8}$ Despite the different clinical presentations, pathogenesis is same in both genders.

\section{Norwood-hamilton classification (male pattern baldness) is as follows}

Type I: Minimal hair loss.

Type II: Minor recession of the frontotemporal hairline.

Type IIIa: The area of recession of the frontotemporal region is almost vertical with the front portion of the ear.

Type IIIv: In this type, hair loss is primarily in the vertex with possibly some frontal recession. 
Type IV: Severe hair loss, especially in the frontal and frontotemporal hair, and significant diffuse hair thinning over the vertex. There is a broad band that separates vertex and the top of hair.

Type V: Hair loss at the vertex region is still separated from the frontotemporal region but the division is much less distinct.

Type VI: The bridge of hair that once crossed the crown is now been lost with only sparse hair remaining.

Type VII: Only a narrow band of hair in a horseshoe shape survives on the sides and back of the scalp.

Here study report an interesting case of severe androgenic alopecia in a post-menopausal woman.

\section{CASE REPORT}

A 68-year-old, postmenopausal lady was admitted in Apollo Hospitals, Ahmedabad on $25^{\text {th }}$ September, 2006 with presenting complaints of increased hair loss from scalp since 3 years, more hair loss since 6 months (male pattern baldness) and excessive growth of hair at unwanted sites since 6 months for which she did regular waxing. She appeared to be psychologically disturbed due to her baldness.

\section{Obstetric history}

- A total 3 FTND - 3 Male child - 2 alive and healthy, 1 died at age of 5 years.

Her last delivery was 36 years back and she had undergone tubal ligation at the same time. She was postmenopausal since 21 years.

She was a known case of diabetes mellitus since 3 years, on ayurvedic treatment, hypertensive since 25 years (on tablet Amlodac AT and tablet Colsprin). She had history of Grandmal epilepsy in 1984, taken antiepileptic treatment for 8 years, not on medication for epilepsy presently. She was taking treatment for hirsutism since July 2006 - tablet Aldactone (100 mg) OD and tablet Finast $(1 \mathrm{mg})$ OD. In view of no relief patient was referred to endocrinologist - where endocrinological work up done and subsequently patient referred to gynecologist.

\section{General examination}

She was averagely built and nourished with male pattern baldness, Norwood - Hamilton grade VII. Excessive hair growth over chest, abdomen. She appeared to be depressed and had low self-esteem.

\section{Local examination}

Vulval hair scanty.

\section{Bimanual examination}

Uterus bulky, both ovaries palpable, left bigger than right.

Clinical diagnosis of alopecia and hirsutism due to hyperandrogenemia secondary to ovarian tumor made and patient investigated for same.

- $\quad 13 / 09 / 06$ - S. Testosterone - $600 \mathrm{ng} / \mathrm{ml}$ (normal range $0.1-0.9 \mathrm{ng} / \mathrm{ml})$.

- 13/09/06 - S. 17 - OH Progesterone - 1.3 ng/ml (normal range in menopausal $0.2-0.9 \mathrm{ng} / \mathrm{ml}$ ).

- 13/09/06 - CT abdomen and pelvis showed B/L ovarian enlargement, right ovary $2.5 \times 2.2 \mathrm{cms}$, left ovary $2.2 \times 2.2 \mathrm{cms}$ with $\mathrm{B} / \mathrm{L}$ adrenal hyperplasia. No free fluid in abdomen, no lymphadenopathy.

- 13/09/06 - CA-125 - 99.35 U/ml. (Normal range: < $35 \mathrm{U} / \mathrm{ml})$

She was having mild polycythemia with $\mathrm{Hb}$ level - 16.3 gm\% and RBC - 5.29 million/cumm.

So, diagnosis of ovarian tumor leading to hyperandrogenemia made. Rest of the investigations were within normal range hence she was taken for abdominal hysterectomy with $\mathrm{B} / \mathrm{L}$ salpingo-oophorectomy on $25 / 09 / 06$. Per-operatively uterus was normal size, right ovary enlarged $(30 \times 20 \times 15 \mathrm{~mm})$. Left ovary normal size adherent to omentum, liver speen-normal, small amount of peritoneal fluid (+), sent for cytology.

Post-operative recovery was uneventful. Histopathology examination showed an encapsulated tumor in right ovary - sex cord stromal tumor consistent with Leydig cell tumor, no evidence of malignancy, left ovary normal.

Peritoneal fluid for cytology - negative for malignant cells.

A 5 weeks post hysterectomy at follow up her hormone levels were as follows

S. Testosterone $0.19 \mathrm{ng} / \mathrm{ml}, \mathrm{S}$. FSH - $67.08 \mathrm{mIU} / \mathrm{ml}, \mathrm{S}$. LH - $32.4 \mathrm{mIU} / \mathrm{ml}$, S. DHEA-s - $77.1 \mathrm{mcg} / \mathrm{dl}$.

Patient showed significant regression of clinical signs and symptoms on follow up after one month. Her scalp hair started growing and she did not require waxing for her unwanted hair growth. Her self-esteem improved and she appeared more confidant.

\section{DISCUSSION}

There are three major sources of androgen production in females, which includes ovaries, adrenal gland and peripheral tissues. The ovary secretes androstenedione and testosterone in little quantities. The theca interna cells of the follicles secrete androgen while stromal cells 
secrete little androgen. In postmenopausal women ovarian secretion of androgen, principally testosterone, persists at a rate only slightly lower than that in younger women, and originates in the stroma, which may be stimulated by the increased levels of luteinizing hormone that are present in larger quantities. ${ }^{9}$

In young women, the adrenal gland secretes dehydroepiandrosterone sulfate and small amounts of androstenedione and testosterone. Half the testosterone that circulates is produced by conversion mainly of androstenedione but also of dehydroepiandrosterone in peripheral tissues. In postmenopausal women the adrenal gland continues to secrete dehydroepiandrosterone sulfate but at a lower rate, with the circulating level decreasing with age. The adrenal secretion of androstenedione and testosterone falls slightly in postmenopausal women, but the peripheral conversion of androstenedione does not appear to decrease with age. However, because the levels of the precursors decrease, the amount of testosterone produced from peripheral tissue decreases, hence the overall production of testosterone is decreased to about half after the menopause.

In postmenopausal women the levels of circulating estrogens are very low, with the circulating androgens at relatively higher concentrations. These women often have signs of androgenic activity principally and increase in facial hair, possible due to a slight increase in $5 \alpha$ reductase activity due to very low levels of estrogen. ${ }^{10}$

Adrenal tumors usually secrete dehydroepiandrosterone sulfate in excess quantities, but some of them mainly secrete testosterone, generally with normal or low dehydroepiandrosterone levels. However, imaging studies in all such cases have good sensitivity.

The present case confirms that androgen secreting tumors represent a diagnostic and therapeutic challenge. They have to be considered in the differential diagnosis of severe hyperandrogenism even in postmenopausal women. Clinical presentation, biochemistry and imaging modalities should allow to detect androgen secreting ovarian tumors while selective venous sampling should be reserved for patients in whom uncertainty remains.

In this case, CT scan revealed larger size of ovaries as compared to her postmenopausal status. Hence the possibility of androgen producing tumor was suspected. Selective catheterization of the ovarian and adrenal veins can be used further as a diagnostic tool to localize the source of androgen in women with hyperandrogenism, but it is a difficult procedure and sometimes yield data that are hard to interpret. So, on strong suspicion of ovarian tumor, patient was subjected to bilateral oophorectomy.

Sertoli - Leydig cell tumors are uncommon tumors of ovary accounting for about $1 \%$ of sex cord stromal tumors. ${ }^{11}$ They constitute between $0.1-0.5 \%$ of all the primary ovarian neoplasms. ${ }^{11}$ They probably arise from the male directed cell rests in the hilum of the ovary from the granulose cells or from teratomas. The tumor produces predominantly androgens and in some cases estrogens. They are typically unilateral and almost exclusively found in women between 20 and 30 years. ${ }^{12,13}$ Reports on diagnosis of this type of tumor after 60 years are rare. ${ }^{14}$

Ovarian virilizing tumors are rare and can lead to assessment difficulties because of their small size. ${ }^{15} \mathrm{~A}$ Sertoli - Leydig cell tumor are androgen producers, they may cause virilization, amenorrhea and other menstrual disorders. However, $50 \%$ of patients show no signs of endocrine disorders. ${ }^{16}$

Approximately $10 \%$ of gonadal stromal (sex cord stromal) tumors of ovary are difficult to classify. In most of these cases, the differential diagnosis is between granulosa and Sertoli - Leydig types. ${ }^{17}$ The prognosis of Sertoli - Leydig cell tumors is usually good and correlates with the stage and degree of differentiation. ${ }^{12,16,18}$

\section{CONCLUSION}

All women with severe hirsutism or androgenic alopecia needs further work up to locate the source of androgen over production. Treatment of basic pathology can cure the disease and prevent from spreading locally or nodally.

Funding: No funding sources Conflict of interest: None declared

Ethical approval: Not required

\section{REFERENCES}

1. Rivera R, Guerra-Tapia A. Management of androgenic alopecia in postmenopausal women. Actas Dermosifiliograficas 2008;99(4):257-61.

2. Pickard-Holley S. The symptom experience of alopecia. Semin Oncol Nurs. 1995;11:235-8.

3. van Zuuren EJ, Fedorowicz Z, Schoones J. Interventions for female pattern hair loss. Cochrane database Syst Rev. 2016;5:CD007628.

4. Camacho FM, Garcia-Hernandez M. Psychological features of androgenetic alopecia. J Eur Acad Dermatol Venereol. 2002;16:476-80.

5. Hamilton JB. Patterened loss of hair in man: types and incidence. Ann NY Acad Sci. 1951;53:708-28.

6. Norwood OT. Incidence of female androgenic alopecia (female pattern alopecia). Dermatol Surg. 2001;27:53-4.

7. Ludwig E. Classification of the types of androgenic alopecia (common baldness) occurring in the female sex. Br J Dermatol. 1977;97:247-54.

8. Levy LL, Emer JJ. Female pattern alopecia: current perspectives. Int J Womens Health. 2013;5:541-56.

9. Longscope C. Adrenal gonadal androgen secretion in normal females. Clin Endocrinol Metab. 1986;15:213-28. 
10. Judd HL, Judd JE, Lucas WE, Yen SSC. Endocrine function of post - menopausal ovary: concentration of androgen and estrogen in ovarian and peripheral venous blood. J Clin Endocrinol Metab. 1974;39:1020-4.

11. Kataria SP, Mishra K, Dev G, Tandon R. Sertoli Leydig cell tumor of ovary with heterologous element: a case report. Indian J Pathol Microbiol. 2005;48(4):493-5.

12. Zaloudek C, Norris HJ, Sertoli - Leydig tumors of ovary: a clinicopathological study of 64 intermediate and poorly differentiated neoplasms. Am J Surg Pathol. 1984;8:405-18.

13. Berker B, Kakukcu C, Dokmeci F, Ensari A. A Sertoli - Leydig cell tumor with Endometrial Hyperplasia in post-menopausal women. J Gynaecol Surg. 2001;17(4):133-6.

14. Schumacher A, Rohde E. A rare case of bilateral Sertoli - Leydig cell tumor (in German). Zentralbl Gynakol. 1991;113:1323-6.

15. Regnier C, Bennet A, Malet D, Guez T, Plantavid M, Rochaix $\mathrm{P}$, et al. Intra operative testosterone assay for virilizing ovarian Tumor topographic assessment: report of leydig cell tumor of the ovary in a perimenopausal women with an adrenal incidentaloma. $\mathrm{J}$ Clin Endocrinol Metab. 2002;87(7):3074-7.

16. Young RH, Scully RE. Ovarian Sertoli - Leydig cell tumors: a clinicopathological analysis of 207 cases. Am J Surg Pathol. 1985;9:543-69.

17. Seidman JD. Unclassified ovarian gonadal stromal tumors: a clinicopathologic study of 32 cases. Am J Surg Pathol. 1996;20(6):699-706.

18. Ayhan A, Tuncer ZS, Hakverdi AU, Yuce K, Ayhan A. Sertoli-Leydig cell tumor of ovary: a clinicopathological study of 10 cases. Eur J Gynaecol Oncol. 1996;17(1):75-8.

Cite this article as: Nahar K, Bohra U, Arya V. Androgenic alopecia in post-menopausal female: a clinical presentation. Int J Reprod Contracept Obstet Gynecol 2020;9:2157-60. 